\title{
WHO FEELS NO FEAR? EXPLORING THE DRIVERS OF ENTREPRENEURIAL FEAR OF FAILURE AMONG NON- ENTREPRENEURS IN SLOVAKIA
}

\author{
Holienka, M., Suchankova, D., Psenak, P.
}

Marian Holienka / Comenius University in Bratislava, Faculty of Management, Department of Strategy and Entrepreneurship, Odbojarov 10, P.O.Box 95, 82005 Bratislava, Slovakia. Email: marian.holienka@fm.uniba.sk

Diana Suchankova / Comenius University in Bratislava, Faculty of Management, Department of Strategy and Entrepreneurship, Odbojarov 10, P.O.Box 95, 82005 Bratislava, Slovakia. Email: diana.suchankova@fm.uniba.sk

Peter Psenak / Comenius University in Bratislava, Faculty of Management, Department of Quantitative Methods, Odbojarov 10,P.O.Box 95, 82005 Bratislava, Slovakia.Email: peter.psenak@fm.uniba.sk

\begin{abstract}
Failure is an inseparable part and probably the most likely outcome of entrepreneurial activity. Fear of failure is among the key factors that hinder individual entry to the entrepreneurial path. While entrepreneurship literature mostly deals with its consequences, considerably lower attention has been paid to understanding its drivers. This is especially true in the Central European region, Slovakia not being exempt. Thus, our paper aims to fill this gap by analysing factors driving the entrepreneurial fear of failure among non-entrepreneur individuals in Slovakia. In doing so, we rely on the 2019 Global Entrepreneurship Monitor data for Slovakia and employ the ordinal logistic regression to test the hypothesised drivers of fear of failure among non-entrepreneur individuals. Our findings suggest that perceived entrepreneurial self-confidence and perceived ease of starting a business significantly reduce fear of failure. These factors are rather of an intrinsic and individual nature (the 'I can do it' factors). Further, in the case of non-entrepreneurs, these self-assessments usually result from expectations rather than from their own actual experience. Yet, the expectations themselves seem to be strong enough to affect the perceived level of fear of failure. We attribute this effect to the so-called failure feedback - an indication of a potential failure.

Implications for Central European audience: Our study contributes to the debate on drivers of individual involvement in entrepreneurship and their specificity in the Central European context. We shed more light on factors influencing the fear of failure - one of the strongest barriers hindering individuals from starting a business. Despite focusing on Slovakia only, our study brings this topic to the table in the region. We contribute to the body of knowledge by suggesting potential patterns behind the fear of failure formation among the non-entrepreneur population, encouraging further investigation in the region and beyond, and proposing the practical implications for entrepreneurship policy, education, and training.
\end{abstract}

Keywords: fear of failure; entrepreneurship; individual-level factors JEL Classification: L26 


\section{Introduction}

The connection between fear and failure is highly relevant in the entrepreneurship context, as failure is an inherent part of each entrepreneurial endeavour (Dutta \& Sobel, 2021), and, in fact, it is one of its most likely results (Shepherd \& Haynie, 2011). Actual business demography statistics evidence this assumption. For example, the 5-year survival rate of new enterprises in the European Union was only 44.6\% in 2018 (Eurostat, 2020). Slovakia is not an exemption with this respect, as only 4 in 10 SMEs born in 2011 were still operating in 2016 (Slovak Business Agency, 2018). Thus, failure can't be avoided in entrepreneurship, and it will always be feared by those considering starting a business or are already involved in any stage of entrepreneurial activity. In fact, the fear of failure occurrence is much higher than an occurrence of the actual failure, and the first arises independently from the latter (Engel et al., 2021). Furthermore, the fear of failure is not only a disturbing individual experience by itself, but it affects many entrepreneurship outcomes, ranging from entrepreneurial orientation (Martins et al., 2018), through opportunity individuation (Wood et al., 2014) and exploitation (Welpe et al., 2012), to entrepreneurial entry (Arenius \& Minniti, 2005; Wennberg et al., 2013) an entrepreneur's actions and behaviours while practising entrepreneurship (Cacciotti et al., 2020). Therefore, as argued by Wyrwich et al. (2019), as the fear of failure has been established as a factor with important consequences in entrepreneurship, its sources and determinants deserve closer examination in order to yield relevant policy recommendations and practitioner guidance. Finally, entrepreneurial fear of failure had been traditionally positioned and studied in a negative connotation, and negative emotional states have been evidenced to negatively impact entrepreneurial potential and intentions (Terek et al., 2017). However, several works demonstrated its motivational effects, too (Martin \& Marsh, 2003; Cacciotti et al., 2016). Such complexity implies an additional argument in favour of further researching this phenomenon.

Thanks to its relevance in entrepreneurship, it is no surprise that fear of failure deserved quite extensive attention among entrepreneurship scholars, including those from Central Europe. Most of the research studies in the region analyse entrepreneurial fear of failure as an explanatory factor of entrepreneurial activity at both individuals (Lukes et al., 2013; Lukes \& Zouhar, 2015) as well as aggregated regional (Dvoulety et al., 2019) and national (Ruminski, 2015; Pilkova \& Holienka, 2017; Lukes, 2017; Grabowska et al., 2018) levels. It has also been studied in the context of gender (Lukes, 2017) or age (Pilkova et al., 2012) differences in entrepreneurship. Several findings indicate that psychosocial factors, including fear of failure, are the key explanatory factors of individual involvement in entrepreneurship (Lukes, 2017; Pilkova \& Holienka, 2017). Thus, there is no doubt that fear of failure deserves close attention in the Central European region. However, studies that would attempt to explain the origins or formation of entrepreneurial fear of failure are scarce. Next, the relevance of this issue in Central Europe is further supported by poor performance of the countries in the region in the 'Second chance' policy dimension of the EU's Small Business Act (European Commission, 2019) (with Slovakia performing the worst in the region), which makes the entrepreneurial failure even more sensitive issue, due to its problematic resolving. In addition, a study by Dvorsky et al. (2020) indicated that perception of business risk (in this case, among the Czech SMEs) is related to perceived expectations related to a business's future. In fact, Szerb et al. (2017) identified risk perception as the main bottleneck pillar of the Czech 
entrepreneurial ecosystem. Interestingly, in the case of Slovakia, the same study pointed out the cultural support to entrepreneurship as the most critical bottleneck (Szerb et al., 2017). Both these pillars fall into entrepreneurial attitudes, the same domain that comprises fear of failure. Further, Dvoulety (2020) indicated that Czech women willing to become selfemployed mostly fear financial insecurity, stress, responsibilities or risks related to setting up a business. All these elements are related to or represent a dimension of business failure. Finally, Dvoulety (2017) found out that in the V4 countries, a higher unemployment rate has been associated with higher levels of entrepreneurship, indicating a potential solution to combat unemployment in difficult times. However, an economic downturn might as well increase the fear that a business could fail. All these perspectives on regional entrepreneurship development point out the important role of fear of failure in explaining individual entrepreneurship inclination, thus underlining the need for its investigation.

Building on the above-mentioned, we share an opinion that understanding the factors related to entrepreneurial fear of failure could help to mitigate its intensity and inhibitive effects on involvement in entrepreneurial activity while leveraging its potentially motivating effects, too. Different effects and mechanisms of fear of failure occur among existing entrepreneurs, compared to those individuals not (yet) taking the entrepreneurial path, and these two approaches require different operationalisations of the construct (Cacciotti et al., 2020). Therefore, exploring this phenomenon in the populations of entrepreneurs vs nonentrepreneurs would require different lenses. In this particular study, our interest will be focused on the pre-entry stage of the entrepreneurship process, as we are targeting fear of failure as one of the impediments discouraging potential future entrepreneurs from entry decisions. Further, as the fear of failure is by nature an intrinsic phenomenon at a level of an individual, we remain focused on searching for individual-level drivers related to its occurrence. Also, as individual-level psychological and perceptual characteristics are to a certain extent changeable, their understanding might evoke actions leading to reduced fear of failure (Croom et al., 2019). Finally, our investigation is geographically limited to Slovakia. Therefore, the research question we attempt to address is: What are the factors driving the entrepreneurial fear of failure among non-entrepreneurs individuals in Slovakia?

The structure of this paper is as follows: First, we present a theoretical background of the entrepreneurial fear of failure, with a specific focus on its contextualisation and its potential drivers. Second, we explain the data and methods used in our analysis. Next, we present our results. Then, our findings and their implications are discussed together with the limitations of our study, followed by a conclusion.

\section{Entrepreneurial fear of failure}

Fear of failure was initially conceptualised in psychology literature as a construct with the motive of avoiding failure and as an opposite to the motive of achieving success (McClelland et al., 1953). Other earlier works characterised fear of failure as a failure avoidance assumption or as an ability to experience shame and humiliation because of failure (Atkinson \& Feather, 1966). Further, fear of failure was also defined as a predisposition to experiencing the anxiety of fear of failure in stressful situations (Atkinson \& Litwin, 1973). These approaches underline both the linkage between assumption and emotional experience, such as feeling ashamed (McGregor \& Elliot, 2005) or feeling anxious (Atkinson \& Litwin, 1973), as well as the importance of situational impulses for activation of this connection. Lazarus (1991) and later Conroy (2001) developed a multidimensional model of fear of failure with the 
purpose to summarise its previous conceptualisations. According to their model, fear of failure is understood as a process of assessing threats in situations of potential failure. Thereby, the anxiety of fear of failure is explained as a concept where people are not only afraid of the fear of failure but especially of the consequences resulting from a failure. Conroy et al. (2003) named such consequences as the unfavourable consequences of failure. Thus, this concept implies that the fear of failure springs from fearing the unfavourable consequences, in particular: 1) fear of experiencing shame and humiliation after failure; 2) fear of being underestimated by others after experiencing a failure; 3) fear of an uncertain future after failure; 4) fear of losing our social attractiveness due to failure, and 5) fear of making other people angry after we fail. So how might people behave in risky situations? Typically, situations in which people evaluate a high probability of a negative outcome (i.e. a failure) will activate the cognitive schemes associated with unfavourable consequences of failure. These schemes can evoke different behavioural responses: an individual is prepared to respond to the threat aggressively (fight); an individual tries to avoid this situation (escape); or an individual is paralysed, unable to do anything (frozen) (Conroy, 2004; Elliot \& Church, 1997). This changing nature of fear, together with different cognitive and behavioural mechanisms, highlighted the fascinating side of fear - the admission that fear can be both friend and foe as well (Martin \& Marsh, 2003).

In the entrepreneurship context, most of the empirical research to date has emphasised the negative role of having a fear of failure on various entrepreneurship-related behaviours and actions. The negative impact of fear of failure has been studied in different stages of entrepreneurial activity. Shinnar et al. (2012) examined the negative impacts of fear of failure on entrepreneurial intention to start businesses. Their study considered a country level and involved China, United States and Belgium. Findings of this comparative study proved a negative relationship between entrepreneurial intention and the fear of failure in all three countries. Therefore, the authors confirmed that individuals who perceive the fear of failure exhibit a decreased entrepreneurial intention. Hessels et al. (2011) examined the probability of restarting a business again after premature discontinuation. Their research was based on the Global Entrepreneurship Monitor (GEM) data. The research clearly proved a higher probability of entrepreneurial engagement after the previous experience. Further, previous entrepreneurial experience leads to decreased fear of failure. Many other studies rely on GEM data, too, as GEM examines fear of failure as a separate variable (e.g. Autio \& Pathak, 2010; Brixy et al., 2012; Wennberg et al., 2013). Unsurprisingly, their results suggested a negative impact of fear of failure on entrepreneurial behaviours. Brixy et al. (2012) confirmed that entrepreneurs in any stage of entrepreneurial activity exhibit much lower levels of fear of a business failure compared to non-entrepreneurs. The same findings were also reported by Arenius and Minniti (2005). However, there are also studies that have not confirmed the negative impact of fear of failure on entrepreneurship and vice-versa. Moreover, they show a positive relationship. For instance, Verheul and Van Mil (2011) aimed their study at nascent entrepreneurs. They hypothesised that fear of failure inhibits the growth of business ventures. However, they found no support for this hypothesis. The sample of 504 nascent entrepreneurial showed the insignificant impact of fear of failure on the decision to grow the venture.

Entrepreneurial fear of failure can be understood in various contextualisations. First, an economic perspective expresses the fear of failure as a phenomenon causing the negative perception of entrepreneurship career choice (Arenius \& Minniti, 2005). Several studies 
suggested that decreasing such negative perceptions increased the probability of choosing to start a business (Langowitz \& Minniti, 2007; Wagner, 2007). Second, a socio-psychological contextualisation explains the fear of failure as a socio-cultural trait that affects the attention of appreciation in society (Gómez-Araujo et al., 2015). According to Hessels et al. (2011) an individual's attitude to failure is influenced by the existence of social norms, which label that failure as a shaming experience. Third, a psychological contextualisation is focused on the personal characteristics of individuals that lead to predictable behaviour in different situations. However, the fact that individuals are influenced by situational characteristics is also important, yet individuals might react quite differently in the same situation. Therefore, the psychological approach oriented to an instant state assumed that behaviour is a function of psychological states that are stimulated by situational characteristics (Leary \& Hoyle, 2009). Certain situational variables cause a change in the psychological state, leading to different behavioural responses. Fear of failure is a temporary cognitive and emotional state triggering recognition of threat from external stimuli, and it is reflected in an individual's behaviour as a failure avoidance (Conroy, 2001). These concepts lead to two different approaches to fear of failure - the approach oriented on temporary psychological state and the approach oriented on long-term psychological state. Moreover, these two approaches enable to explain different nature, experience, and different behavioural consequences from fear of failure. Nevertheless, while recent studies clarified the role of fear of failure in entrepreneurship, there are still lots of unanswered questions, especially related to the essence of the fear of failure, as well as its relationship to the entrepreneurship process (Cacciotti \& Hayton, 2015). Especially, using different contextualisations (economic, social-psychological, psychological) to explain the nature of fear of failure differently resulted in the absence of a clear conceptualisation of this phenomenon. Lastly, while the very recent works extended the attention to entrepreneurial fear of failure from a pre-startup perspective also to examine its role and nature in the later stages of an entrepreneurship process (Cacciotti et al., 2020), we attach our study to the pre-entry context, as we focus our investigation on non-entrepreneurs.

On the other hand, studying the nature, processing, and consequences of fear of failure alone is not sufficient, as there is also a need to consider the influence of external factors. Conroy (2001) endorsed the important role of external circumstances influencing fear of failure, especially when entrepreneurship is concerned. When we consider the dynamic nature of entrepreneurship, a more complicated relationship between individuals and the external environment can be expected, compared to what Lazarus (1991) expressed in the theory of cognitive evaluation (McMullen \& Dimov, 2013). According to this theory, in relatively stable situations (such as sports match or school test), the external environment is only considered as a trigger of internal processes leading to certain behaviours. However, in highly dynamic situations such as entrepreneurship, the fear of failure can be expected to be dynamic as well. In such situations, fear is based on intensive interaction between cognitive evaluation and emotional experience reacting to external social impulses. And this interaction can constantly change (Randolph-Seng et al., 2014).

\subsection{What drives entrepreneurial fear of failure}

In search of factors potentially related to the entrepreneurial fear of failure, our attention will remain focused on individual attributes, which have been established in entrepreneurship literature as important factors affecting individual entrepreneurial actions and outcomes (e.g. Arenius \& Minniti, 2005). Moreover, as these attributes are often changeable by the controlled 
actions of an individual, understanding their role in forming the fear of failure could indicate the way to reduce the fear of failure and its consequent negative effects (Croom et al., 2019).

First, the individual self-confidence about having the capacity to successfully start and run a business is frequently declared as an important driver of entrepreneurship-related outcomes and attributes (Boyd \& Vozikis, 1994). Entrepreneurial self-confidence is related to the interlinked concepts of knowledge, skills, and abilities (Markman, 2012), together creating a set of entrepreneurial competencies (Holienka, 2018). In relation to an individual's fear of failure, self-confidence might play an important role. As Cacciotti et al. (2016) argue in their reconceptualisation of entrepreneurial fear of failure, the perceived ability is one of the main individual's sources of fear of failure. More specifically, it comprises an individual's concern about his/her ability to perform tasks related to the process of exploiting an opportunity and consequent setting up and developing a business venture. During this process, a fear of failure arises as a result of tension between the need to execute certain tasks and an individual's level of competence, especially in cases of dissatisfactory performance and consequent self-blame and feeling of responsibility (Cacciotti et al., 2016). Further, Mitchell and Shepherd (2011) suggest that an opposite direction in the relationship between selfconfidence and fear of failure exists, too. As they argue, if an individual encounters a failure, it might lead to doubts about possessing abilities required to succeed, and the person gradually loses resilient confidence of ability to control events to achieve the desired goals. Finally, entrepreneurial self-confidence and fear of failure are frequently researched together in the context of entrepreneurship-related aspects, such as opportunity individuation (Wood et al., 2014), entrepreneurial orientation (Martins et al., 2018) or entrepreneurial activity (e.g. Arenius \& Minniti, 2005; Wennberg et al., 2013; Holienka et al., 2016; Boudreaux et al., 2019). Building on the above-mentioned, we propose the following hypothesis:

H1: Perceived self-confidence about own entrepreneurial capacity is negatively related to the entrepreneurial fear of failure among non-entrepreneurs.

Second, an important role is attributed to an individual's entrepreneurship-relevant social capital, as the fear of failure seems to be situated in a larger social context (Cacciotti et al., 2016). The general concept of social capital refers to an individual's social structures, networks and memberships that enable him/her to extract benefits through the social exchange (Portes, 1998). Its entrepreneurship-specific connotation refers to external knowledge provided by other people in one's environment (Ramos-Rodríguez et al., 2010) and investment of social resources with hope for return, taking place in an individual's network through social interactions (Anderson et al., 2007). In the case of non-entrepreneurs, other individuals within their social networks who had a recent own start-up experience can be considered as one of the most relevant sources of entrepreneurship-relevant social capital. In fact, several empirical studies confirmed that individuals with self-employed peers within their networks are more likely to become entrepreneurs (e.g. Vancea \& Utzet, 2017). A person who managed to set up an own business acts as living evidence that entrepreneurial outcomes are achievable (DeClerq \& Arenius, 2006), which in turn might act positively towards an individual's entrepreneurship inclination by reducing ambiguity regarding entrepreneurship (Minniti, 2005). Thus, knowing others who managed to enter the entrepreneurial path themselves should reduce the fear of failure that would prevent an individual from making the same decision. Former empirical research already yielded some support to this perspective. For example, Wyrwich et al. (2019) have found out that, on the 
regional level, exposure to successful entrepreneurs reduces entrepreneurial fear of failure, while being exposed to business failures has an opposite effect. Also, Croom et al. (2019) found out that personally knowing an entrepreneur generally reduces fear of failure, while the relationship is stronger for men compared to women. Finally, Trang et al. (2019) argue that individuals in social contact with entrepreneurs tend to have lower fear of failure. Based on the above-mentioned, we propose the following hypothesis:

\section{H2: Knowing individuals who recently started a business is negatively related to entrepreneurial fear of failure among non-entrepreneurs.}

Third, several authors have argued that contextualisation plays an important role in relation to entrepreneurial fear of failure (e.g. Boudreaux et al., 2019, Dutta \& Sobel, 2021). We understand the perception of good opportunities for starting a business in one's area as a good proxy that captures the context in which an individual's entrepreneurial potential is to be realised, as well as the individual subjective interpretation of this context. In other words, we see opportunity perception as an intercept between an objective context and its subjective interpretation. So, it is both the perceived context and perceived individual ability that influences whether one fears to start a business. Particularly, lower opportunity perception should reflect a sceptical interpretation of the context and, consequently, yield a higher fear of failure that inhibits entry into entrepreneurship. Support for this perspective can also be found in the empirical literature. For example, Heinzel et al. (2014), based on their countrylevel analysis, argued that people are less afraid to fail when their country's economy is growing (irrespective of its actual wealth and development) and tend to fear more in contexts with lower start-up activity. As positive economic development is typically associated with good business opportunities, while the lack of new entrepreneurs might be linked to poor availability of business opportunities, their findings provide support to our perspective. Also, Welpe et al. (2012), in their experimental study, argue that fear as an avoidance-oriented opportunity-evoked emotion decreases actual opportunity exploitation and moderates the mediation of the opportunity characteristics and exploitation by evaluation. Simply said, they empirically confirmed the connection between opportunity evaluation and fear of failure. Based on the above-mentioned, we hypothesise:

H3: Perception of good entrepreneurial opportunities is negatively related to entrepreneurial fear of failure among non-entrepreneurs.

Fourth, entrepreneurship literature emphasises fear of failure as a reaction to perceived obstacles during setting up and/or running a business (Cacciotti et al., 2016; Engel et al., 2021). In our opinion, this perspective is relevant in broader entrepreneurship connotation and thus can be extended to a pre-startup phase, too. Therefore, in the case of nonentrepreneurs, perceived obstacles and difficulties related to starting a business become relevant in relation to an individual's entrepreneurial fear of failure. In general, the mechanism behind the influence of perceived or experienced obstacles during the entrepreneurship process and consequent activation of fear of failure is attributed to the so-called failure feedback (Bélanger et al., 2013), i.e. feedback indicating a high probability of failure related to a specific situation. While considering that starting a business is easy shall not discourage potential entrants from becoming entrepreneurs, perceiving the obstacles and difficulties in this process should trigger an individual's fear of failing as a reaction to the expected barriers, leading to reduced start-up appetite. The influence of obstacles on entrepreneurial fear of failure has also been established empirically. For example, in their study, Kollmann et al. 
(2017) demonstrated that obstacles in the early phases of the founding process activate individuals' fear of failure. Moreover, they argue that fear of failure has a critical role in mediating the effect of obstacles on entrepreneurial activity. Therefore, we propose the following hypothesis:

\section{H4: Perceived ease of starting a business is negatively related to entrepreneurial fear of failure among non-entrepreneurs.}

In addition to the individual entrepreneurship-specific attributes that have been addressed above, we also consider the individual demographic attributes, namely gender, age, and educational attainment, as factors potentially related to entrepreneurial fear of failure. Empirically, they will be investigated as control variables in our analysis.

The entrepreneurial fear of failure among genders has been the subject of many studies (Wagner \& Sternberg, 2004; Minniti \& Nardone, 2007; Wagner, 2007; Koellinger et al., 2013), with a typical finding that women tend to be more afraid of failure than men. Moreover, higher fear of failure is often seen as one of the origins of women's reduced tendency to start a business. While it is attributed to dispositional differences between men and women, a theoretical justification for these differences is often lacking. However, in line with the previous research, we would expect gender to be a significant factor in relation to fear of failure, with women tending to fear entrepreneurial failure more than men.

As far as age is concerned, there are several aspects of ageing that might be relevant for fear of failure. For example, increased age typically goes hand in hand with accumulated human capital (Botham \& Graves, 2009) and larger networks (De Bruin \& Firkin, 2001), even though their business relevance typically depends on the nature of previous work experience. In addition, ageing is also related to changes in factors such as family care and income securing responsibilities, accumulated financial resources and income diversification, opportunity costs of other career alternatives, or tendencies to realise personal aspirations, and the development patterns of these attributes with increasing age might be different. Yet, Pilkova et al. (2012) indicated that the senior population was characterised by a higher occurrence of entrepreneurial fear of failure than the overall adult population. However, interestingly, both Cerveny et al. (2016) and Rehak et al. (2017) found out that while fear of failure is a significant barrier to starting a business within the senior population, its strength is lower when compared to the overall adult population, or to populations of youth and young adults. Nevertheless, we expect to see a higher entrepreneurial fear of failure with increased age.

Finally, educational attainment is typically linked to individual human capital (Becker, 1993). While general education might not necessarily be relevant for a particular business endeavour (Unger et al., 2011; Davidsson \& Gordon, 2012), still it could positively influence general self-confidence and perceived ability (Cacciotti et al., 2016) to perform required tasks in various stages of entrepreneurship process. Thus, we expect to see a reduced fear of failure with higher levels of educational attainment.

\section{Data and methods}

Our study is based on the Global Entrepreneurship Monitor (GEM) 2019 data for Slovakia. GEM is the world's largest academic study on entrepreneurship, annually analysing entrepreneurial attributes and activities in tens of economies worldwide (Bosma et al., 2020). 
The GEM consortium comprising of national teams undertakes year two national surveys the National Expert Survey (NES) and the Adult Population Survey (APS). The latter is the basis of our analysis. The APS uses an internationally harmonised survey instrument to collect data from nationally representative samples of working-age adults, investigating their entrepreneurial activities, attitudes, motivations, and aspirations. The overall GEM 2019 APS sample for Slovakia is comprised of 2001 individuals. The respondents were randomly selected from adult 18-64 years population, using a combination of direct sampling of individuals (selected using random digit dialling to mobile phone numbers) and sampling individuals from households (households approached by calling fixed lines from a list of households, particular respondent selected using the 'next birthday' method). Also, soft quotas for age category, gender, and region (NUTS 3 level) were adopted in sample collection to satisfy the representativeness criteria.

As our study focuses on non-entrepreneurs, we filtered out all individuals who owned and managed a business (in any stage, i.e. nascent, new or established). Also, we deleted all cases with missing values for the dependent variable. This initial filtering resulted in our final sample of 1603 adult population individuals, comprising 723 male and 880 female respondents with an average age of 44.28 years (minimum $=18$ years, maximum $=64$ years).

Our dependent variable characterises the individual's revealed entrepreneurial fear of failure. It is measured using a single Likert-type item in the standard GEM questionnaire. In particular, the respondents indicate their level of agreement with the statement that they would not start a business for fear it might fail, where $1=$ strongly disagree and $5=$ strongly agree.

Based on our hypotheses developed above, we employed the following independent variables (all measured using the items from the standard GEM questionnaire) in our analysis:

- Entrepreneurial self-confidence: respondents indicated their level of agreement about personal possession of knowledge, skills and experience required to start a new business, measured on the 5 -point Likert scale $(1=$ strongly disagree to $5=$ strongly agree).

- Knowing other early-stage entrepreneurs: respondents were asked how many people who have started a business or become self-employed in the recent two years do they personally know ( $0=$ none, $1=$ one, 2 = two to four, $3=$ five or more).

- Perception of good entrepreneurial opportunities: respondents were asked whether they agree with the statement that, in the six months following the survey, good opportunities for starting a business would exist in the area where they lived. The item was measured using a 5-point Likert-type scale $(1=$ strongly disagree to $5=$ strongly agree).

- $\quad$ Perceived ease of starting a business: respondents were inquired if they agreed with the statement that in a country where they lived, it would be easy to start a business. The item was measured using a 5-point Likert-type scale ( 1 = strongly disagree to 5 = strongly agree).

Moreover, we employed a set of control variables to control for the respondents' age category ( 18 to 24,25 to 34,35 to 44,45 to 54 , or 55 to 64 years), gender (male $=1$, female $=2$ ) and the highest educational attainment (according to the UN harmonised educational attainment, ranging from pre-primary $=0$ to doctor or equivalent $=8$ ). 
As for the methods used, due to the ordered categorical character of our dependent variable, we have employed the ordinal logistic regression to estimate how the independent and control variables predict an individual's entrepreneurial fear of failure. We conducted several steps to ensure that the selected method is suitable for our analysis. In regressions where more variables exist, two or more variables can correlate with each other. A specific case of correlation where multiple variables correlate with each other is called multicollinearity. This means that there is an unwanted redundancy between different predictor variables. Thus, when constructing our models, we accounted for potential multicollinearity. Also, we tested whether the relationship between each pair of outcome groups is the same in every value to satisfy the proportional odds assumption. Because the relationship between all pairs of groups was the same, there was only one set of coefficients. Hence, we could use the ordinal outcomes.

\section{Results and discussion}

In the initial step of our analysis, we combined all the independent variables' sums into one aggregated variable, which was utilised to check whether we can visualise the differences in fear of failure based on the combined values of the independent variables under analysis. As seen in Figure 1 below, our findings indicate a difference in the means of the boxplots in the case of aggregated variables' values. Also, the interquartile ranges or extreme values are different. Thus, we assume that different levels of the selected independent variables imply different levels of fear of failure. Moreover, we observed decreasing means of the aggregated variable in case of the higher levels of fear of failure (values 4 and 5), which is in line with the assumptions that informed our hypotheses.

Figure 1 | Aggregated independent variables vs fear of failure

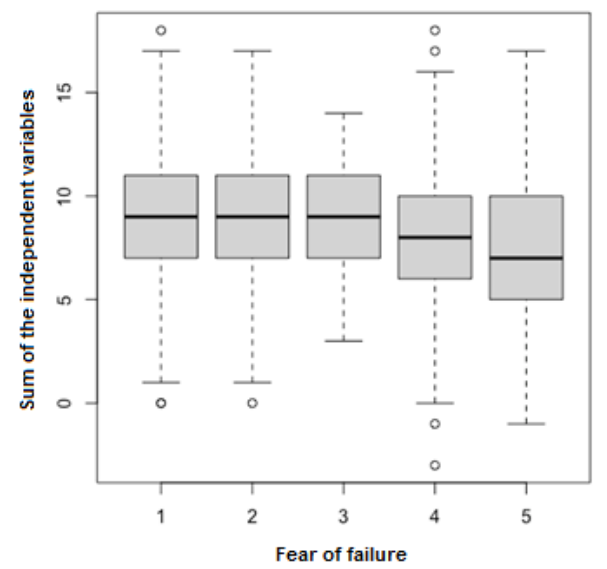

Source: authors' own calculations based on GEM 2019 data

In the actual core of our analysis, we conducted an ordinal logistic regression and estimated a series of models to predict the fear of failure given our independent and control variables. Model 1 contains all independent variables considered in our analysis. Model 2 was estimated as a separate econometric model for control variables to satisfy the acceptable level of multicollinearity. Finally, we also attempted to estimate a model combining only the significant variables from previous models, to inquire whether the variables complement each other. 
However, the inner multicollinearity appeared to be problematic, the control variables lost their significance, and the odds ratios of the significant independent variables were very similar, so the resulting model added no value to our exploration. Thus, we remained focused on the first two models, and we built our findings around the statistically significant independent variables. Both models are depicted in Table 1, while their results are interpreted and discussed below.

Table 1 | Drivers of entrepreneurial fear of failure (Ordinal logistic regression results)

\begin{tabular}{|c|c|c|c|c|}
\hline \multirow[t]{2}{*}{ Coefficients } & \multirow{2}{*}{$\begin{array}{c}\text { Model } 1 \\
\text { Value (SE.) }\end{array}$} & \multicolumn{3}{|c|}{ Model 2} \\
\hline & & OR & Value (SE.) & OR \\
\hline Opportunities perception & $0.024(0.030)$ & 1.024 & & \\
\hline Self-confidence & $-0.289^{\star * *}(0.031)$ & 0.749 & & \\
\hline Perceived ease of starting-up & $-0.095^{\star \star}(0.034)$ & 0.910 & & \\
\hline Knowing entrepreneurs & $0.001(0.038)$ & 1.001 & & \\
\hline Age category & & & $0.043(0.036)$ & 1.044 \\
\hline Gender & & & $0.229^{\star *}(0.090)$ & 1.258 \\
\hline Educational attainment & & & $-0.048^{* \star}(0.021)$ & 0.953 \\
\hline \multicolumn{5}{|l|}{ Intercepts } \\
\hline $\begin{array}{l}\text { Strongly disagree|Somewhat } \\
\text { disagree }\end{array}$ & $-2.385^{\star \star \star}(0.142)$ & & $-1.034^{\star * \star}(0.241)$ & \\
\hline $\begin{array}{l}\text { Somewhat disagree|Neither } \\
\text { agree nor disagree }\end{array}$ & $-1.281^{\star * *}(0.133)$ & & $0.028(0.239)$ & \\
\hline $\begin{array}{l}\text { Neither agree nor } \\
\text { disagree|Somewhat agree }\end{array}$ & $-1.061^{\star \star \star}(0.132)$ & & $0.237(0.239)$ & \\
\hline $\begin{array}{l}\text { Somewhat agree|Strongly } \\
\text { agree }\end{array}$ & $0.291^{\star *}(0.129)$ & & $1.526^{\star \star \star}(0.242)$ & \\
\hline Observations & 1603 & & 1603 & \\
\hline Nagelkerke $\mathbf{R}^{2}$ & 0.068 & & 0.008 & \\
\hline Residual deviance & 4730.468 & & 4823.605 & \\
\hline AIC & 4746.468 & & 4837.605 & \\
\hline
\end{tabular}

Note: ${ }^{* * *}$ statistical significance on $1 \%,{ }^{* *}$ statistical significance on $5 \%$

Source: authors' own calculations

The results of Model 1 suggest that two out of four analysed independent variables were significant - entrepreneurial self-confidence and perceived ease of starting a business. Holding all other variables constant, a single unit increase in entrepreneurial self-confidence was associated with a $25.1 \%$ decrease in the odds of having a fear of failure that would prevent an individual from starting a business (Odds ratio $=0.749,95 \% \mathrm{Cl}=-0.35--0.23, \mathrm{p}$ $=0.000)$. Therefore, we accept our hypothesis $\mathrm{H} 1$ : Perceived self-confidence about own entrepreneurial capacity is negatively related to the entrepreneurial fear of failure among non- 
entrepreneurs. Further, holding all other variables constant, a single unit increase in perceived ease of starting a business was associated with a $9 \%$ decrease in the odds of having a fear of failure preventing an individual from business entry (Odds ratio $=0.910,95 \%$ $\mathrm{Cl}=-0.16--0.03, \mathrm{p}=0.005)$. Based on this result, we also accept our hypothesis $\mathrm{H} 4$ : Perceived ease of starting a business is negatively related to entrepreneurial fear of failure among non-entrepreneurs. Finally, due to statistical insignificance of perception of good business opportunities and knowing early-stage entrepreneurs in relation to fear of failure, we have to reject the remaining hypotheses (i.e. $\mathrm{H} 2$ : Knowing individuals who recently started a business is negatively related to entrepreneurial fear of failure among non-entrepreneurs; and H3: Perception of good entrepreneurial opportunities is negatively related with entrepreneurial fear of failure among non-entrepreneurs) proposed for our investigation.

Model 2 estimates the fear of failure employing the control variables, two of them were found to be significant, namely gender and educational attainment. More specifically, holding all other variables constant, the odds of non-entrepreneurs having a higher fear of failure was $26 \%$ higher if the respondent was female as opposed to being a male (Odds ratio $=1.258$, $95 \% \mathrm{Cl}=0.05-0.41, \mathrm{p}=0.011)$. Also, holding all other variables constant, a single unit increase in educational attainment was associated with a $5 \%$ decrease in the odds of having a fear of failure that would inhibit an individual from starting a business (Odds ratio $=0.953$, $95 \% \mathrm{Cl}=-0.09--0.01, \mathrm{p}=0.025)$. Thus, two of our expectations regarding the relationship between entrepreneurial fear of failure and demographic factors have been confirmed. Contrary, we found no significant evidence on the relationship between the fear of failure and age category.

Our findings suggest that the factors affecting non-entrepreneur individuals' hesitance to start a business for fear it might fail (i.e. the entrepreneurial fear of failure from the perspective of a pre-entry barrier) are rather of intrinsic and individual nature, instead of being anchored in business environment or individual's social networks. Namely, we argue that self-confidence about entrepreneurship-related skills, knowledge, and experience, together with own subjective perception of difficulty to start a business, are the key drivers reducing the prohibitive effect of fear of failure on potential entrepreneurship entry. On the contrary, neither the perception of good opportunities to start a business nor the extent of an individual's network among early-stage entrepreneurs seems to significantly decrease the fear of failure. Simply said, the 'I can do it' factors play a greater role compared to the 'opportunities are favourable' or 'the others made its factors. In our opinion, this finding yields a crucial implication towards looking for ways to reduce the negative effects of entrepreneurship fear of failure among those individuals who are currently not yet involved in the business. Also, it is a positive message, as the individual fear of failure-related attributes is easier to control and change (Croom et al., 2019). The significant role of entrepreneurship-related selfconfidence is in line with the work of Cacciotti et al. (2016), who argued that perceived ability to perform tasks within an entrepreneurship process influences the tension between the need to execute and an individual's level of competence, which consequently evokes fear of failure. While in the case of non-entrepreneurs, there is typically no actual experience in performing the entrepreneurship-related tasks, and thus the opinion on own level of entrepreneurial competencies can't be objectively informed. The expectations about doing so seem to be strong enough to affect the perceived level of fear of failure. This is in line with Engel et al. (2021), who argue that fear of failure arises independently from the actual failure occurrence. Similarly, the role of perceived ease of starting a business could be based on a combination 
of individual self-confidence and perceived ability with perceived obstacles related to setting up a business (Cacciotti et al., 2016; Kollmann et al., 2017; Engel et al., 2021). This perception is probably also based on expectations about potential challenges, should an individual have decided to pursue this direction, even though no such effort has taken place so far. Again, these findings yield useful implications for initiatives aimed at moderating the entrepreneurial fear of failure among people who have not entered entrepreneurship yet. The importance of expected tensions between actual vs required competencies and expected obstacles in entering the entrepreneurship process might be attributed to the so-called failure feedback (Bélanger et al., 2013), i.e. feedback indicating a high probability of failure related to a specific situation that consequently activates the fear of failure itself.

As far as implications for practice are concerned, we believe that our findings on the key role of intrinsic, individually anchored factors, together with the importance of individual expectations about probability of failure, are especially relevant with this respect. In fact, these findings indicate which areas should entrepreneurship policymakers, together with education and training providers, focus on to reduce the prohibitive effects of entrepreneurship fear of failure on potential business path entrants. More specifically, initiatives aimed at potential entrepreneurs should be focused on making them aware of entrepreneurial competencies related to different stages of starting up and running a business, offering a realistic reflection, and helping to develop a learning plan to improve those competencies where gaps will be identified. That means designing and delivering a personalised entrepreneurship training based on an individual's assessment, possibly accompanied by individual mentoring. Also, in the case of online self-administered training, innovative automated online diagnostic tools could be used to measure trainees' competencies and adjust the learning path accordingly. In both these cases, a modular training curriculum should be employed. These education and training designs could be used in both educational system settings (especially at HE level) subsidised entrepreneurship training (typically provided by national or regional agencies and authorities) and commercial entrepreneurship training offerings. They could complement the currently available schemes in Slovakia that are typically pre-defined and firmly structured and do not allow personalisation. Thanks to such training, hand in hand with reduced negative effects of the fear of failure, participants will generally be better equipped for running a business. Also, to reduce their fear of failure, potential entrepreneurs should be better prepared for coping with obstacles related to starting and running a business. And, especially, their preparation should also include instructions on coping with and resolving failure, as individuals frequently fear merely the potential consequences rather than the failure itself. Thus, this topic, currently quite overlooked, deserves specific attention in entrepreneurship education and training. More specifically, the examples of potential interventions include business training on crisis management and resolving business failure, psychological preparation, and individual coaching on coping with failure, or inspirational talks of entrepreneurs who failed and restarted again. These are currently very hard to find in Slovakia. Finally, such specific interventions could be further targeted to particularly underrepresented groups in relation to entrepreneurship (such as women, seniors, or minorities), which could contribute to their increased participation in entrepreneurial activity.

Further, we also see several implications that our findings yield for further research. For example, a deeper investigation on relationships and mechanisms between self-confidence, perceived obstacles, failure and its consequence expectations, and formation of fear of failure 
would be beneficial in the Central European context. Our study suggests a pattern, but a more robust inquiry is needed to explore it in different contexts and sufficient depth. Quite intensive and deep attention to the fear of failure has been recently paid in an international context (e.g. Cacciotti et al., 2016; Kollmann et al., 2017), and new research instruments have been developed (Cacciotti et al., 2020). Our study indicates the relevance of this research direction in Slovakia, so we call for its expansion (not only) across Central European countries. Entrepreneurship theory and practice in Central Europe would benefit from replication of similar inquiries in different countries, perhaps even regions (Wyrwich et al., 2019), to confirm the validity of fear of failure key drivers and, most importantly, to inform the local policymakers on how to approach those whose fear of failure is inadequately blocking them from starting a business. To develop further understanding, researchers in the region should employ specifically tailored survey instruments in quantitative studies and then execute qualitative inquiry to elaborate on main findings in more detail. Also, longitudinal research designs are encouraged to track how fear of failure acts as a distinguishing trait vs a temporary state (Cacciotti \& Hayton, 2015) and what are the consequences in relation to entrepreneurship over an individual's pathway. Next, we strongly support expanding the attention also to already active entrepreneurs and further develop this research stream in the region, alongside the more established focus on non-entrepreneurs or potential entrepreneurship entrants. Finally, we also encourage future research to focus on the potential changes in the patterns related to fear of failure and its effects on entrepreneurship outcomes in the context of pandemic and future post-pandemic settings. Providing the fear of failure is embedded in the situation and context, the COVID-19 crisis, its impacts on business, and related government responses could have significantly affected individuals' entrepreneurship fear of failure and its consequences.

Finally, we understand that our study is not exempt from limitations. First, our data are crosssectional by nature, and all items originate from the same research instrument, which, together with the adopted testing method, might yield an argument that the findings cannot be interpreted unambiguously as causal relationships. While respecting this limitation, we rely on the solid theoretical background as well as strong evidence provided by our data and feel confident about the qualitative nature of our findings. Second, our study focuses on Slovakia only, which sets a limitation to the generalisation and transferability of our findings. In fact, with this respect, our aim was to obtain a specific and focused country-level insight while at the same time suggesting some patterns that might be valid irrespective of a particular socioeconomic context, especially in the Central European region. Yet, these require further examinations, as already indicated above. Third, due to the nature of the data employed (single-item variables obtained using a quantitative survey), we were not able to inquire deeper into the investigated constructs. However, we believe that in our paper, this limitation is sufficiently compensated by the sample size and methodological rigour. Further research can expand our findings and investigate the proposed and identified relationships in more detail while adopting different research strategies and designs.

\section{Conclusion}

To conclude, our study on drivers of entrepreneurial fear of failure among non-entrepreneurs in Slovakia unveils that perceived entrepreneurial self-confidence together with perceived ease of starting a business significantly reduce individual fear of failure that would discourage them from starting a business. These factors are rather of an intrinsic and individual nature 
(the 'I can do it' factors), instead of being anchored in the business environment or individual's social networks (the 'opportunities are favourable' or 'the others made its factors). Further, while non-entrepreneurs usually haven't had a chance to test their ability or the obstacles related to setting up a business in practice, their expectations themselves seem to be strong enough to affect the perceived level of fear of failure. We attribute this effect to the so-called failure feedback (Bélanger et al., 2013) - an indication of a potential failure. We see these findings as to the main contribution of our research to the entrepreneurship literature in the region and beyond. Further, as suggested by our findings, a better preparedness of nonentrepreneurs could help to lower the effect of fear of failure as a barrier to their entrepreneurship entry decisions. Therefore, we recommend entrepreneurship support policies, education, and training to explicitly address the abilities of potential future entrepreneurs to successfully perform various tasks and roles related to setting up and running a business, address potential related obstacles, and cope with and resolve the potential business failure. This could lead to their enhanced entrepreneurial self-confidence, reduced expectations of obstacles, and decreased fear of business failure consequences.

\section{Acknowledgement}

This work was supported by the Slovak Research and Development Agency under Contract no. APVV-19-0581.

\section{References}

Anderson, A., Park, J., \& Jack, S. (2007). Entrepreneurial social capital. Conceptualising social capital in new high-tech firms. International Small Business Journal, 25(3), 245-272. https://doi.org/10.1177/0266242607076526

Arenius, P., \& Minniti, M. (2005). Perceptual variables and nascent entrepreneurship. Small Business Economics, 24(3), 233-247. https://doi.org/10.1007/s11187-005-1984-x

Atkinson, J. W., \& Feather, N. T. (1966). A theory of achievement motivation. Wiley.

Atkinson, J. W., \& Litwin, G. H. (1973). Achievement motive and test anxiety conceived as motive to approach success and motive to avoid failure. In D. C. McClelland, \& R. S. Steele (Eds.). Human motivation: A book of readings (pp. 145-163). General Learning Press.

Autio, E., \& Pathak, S. (2010). Entrepreneur's exit experience and growth aspirations. Frontiers of Entrepreneurship Research, 30(5), 2.

Becker, G. S. (1993). Human capital: A theoretical and empirical analysis with special reference to education (3rd ed.). University of Chicago Press.

Bélanger, J. J., Lafrenière, M.-A. K., Vallerand, R. J., \& Kruglanski, A. W. (2013). Driven by fear: The effect of success and failure information on passionate individuals' performance. Journal of Personality and Social Psychology, 104(1), 180-195. https://doi.org/10.1037/a0029585

Boudreaux, C. J., Nikolaev, B. N., \& Klein, P. (2019). Socio-cognitive traits and entrepreneurship: The moderating role of economic institutions. Journal of Business Venturing, 34(1), 178-196. https://doi.org/10.1016/j.jbusvent.2018.08.003

Bosma, N., Hill, S., Ionescu-Somers, A., Kelley, D., Levie, J., \& Tarnawa, A. (2020). Global Entrepreneurship Monitor 2019/2020 Global Report. Global Entrepreneurship Research Association (GERA). https://www.gemconsortium.org/file/open?fileld=50691 
Botham, R., \& Graves, A. (2009). The grey economy: How third age entrepreneurs are contributing to growth. NESTA Research Report. https://media.nesta.org.uk/documents/the_grey_economy.pdf

Boyd, N. G., \& Vozikis, G. S. (1994). The influence of self-efficacy on the development of entrepreneurial intentions and actions. Entrepreneurship Theory and Practice, 18(4), 63-77. https://doi.org/10.1177/104225879401800404

Brixy, U., Sternberg, R., \& Stüber, H. (2012). The selectiveness of the entrepreneurial process. Journal of Small Business Management, 50(1), 105-131. https://doi.org/10.1111/j.1540627X.2011.00346.X

Cacciotti, G., \& Hayton, J. C. (2015). Fear and entrepreneurship: A review and research agenda. International Journal of Management Reviews, 17(2), 165-190. https://doi.org/10.1111/ijmr.12052

Cacciotti, G., Hayton, J. C., Mitchell, J. R., \& Giazitzoglu, A. (2016). A reconceptualisation of fear of failure in entrepreneurship. Journal of Business Venturing, 31(3), 302-325. https://doi.org/10.1016/j.jbusvent.2016.02.002

Cacciotti, G., Hayton, J. C., Mitchell, R. J., \& Allen, D. G. (2020). Entrepreneurial fear of failure: Scale development and validation. Journal of Business Venturing, 35(5), 106041. https://doi.org/10.1016/j.jbusvent.2020.106041

Cerveny, J., Pilkova, A., \& Rehak, J. (2016). Senior entrepreneurship in European context: Key determinants of entrepreneurial activity. Ekonomicky Casopis/Journal of Economics, 64(2), 99117.

Conroy, D. E. (2001). Fear of failure: An exemplar for social development research in sport. Quest, 53(2), 165-183.

Conroy, D. E., Elliot, A. J., \& Hofer, S. M. (2003). A 2×2 achievement goals questionnaire for sport: Evidence for factorial invariance, temporal stability, and external validity. Journal of Sport and Exercise Psychology, 25(4), 456-476. https://doi.org/10.1123/jsep.25.4.456

Conroy, D. E. (2004). The unique psychological meanings of multidimensional fears of failing. Journal of Sport and Exercise Psychology, 26(3), 484-491. https://doi.org/10.1123/jsep.26.3.484

Croom, R. M., Vogel, A. T., Campbell, E. A., \& Zambelli, L. (2019). Not afraid: Mitigating fear of failure in entrepreneurial entry decisions. Journal of Business and Entrepreneurship, 30(2), 13-27.

Davidsson, P., \& Gordon, S. (2012). Panel studies of new venture creation: A methods focused review and suggestions for future research. Small Business Economics, 39(4), 853-876. https://doi.org/10.1007/s11187-011-9325-8

De Bruin, A., \& Firkin, P. (2001). Self-employment of the older worker. Labour Market Dynamics Research Programme, Working Paper No. 4. Massey University. https://citeseerx.ist.psu.edu/viewdoc/download?doi=10.1.1.598.911\&rep=rep1\&type=pdf

DeClerq, D., \& Arenius, P. (2006). The role of knowledge in business start-up activity. International Small Business Journal, 24(4), 339-358. https://doi.org/10.1177/0266242606065507

Dutta, N., \& Sobel, R. S. (2021). Entrepreneurship, fear of failure, and economic policy. European Journal of Political Economy, 66, 101954. https://doi.org/10.1016/j.ejpoleco.2020.101954

Dvorsky, J., Kozubíkova, L., \& Bacova, B. (2020). The perception of business risks by SMEs in the Czech Republic. Central European Business Review, 9(5), 25-44. https://doi.org/10.18267/j.cebr.250

Dvoulety, O. (2017). What is the relationship between entrepreneurship and unemployment in Visegrad countries? Central European Business Review, 6(2), 42-53. https://doi.org/10.18267/j.cebr.179 
Dvoulety, O., Pilkova, A., Mikus, J., \& Rimska, M. (2019). Entrepreneurial activity in Slovakia: Selected regional aspects and the role of governmental environment. In O. Dvoulety, M. Lukes \& J. Misar (Eds.), Proceedings of the 7th International Conference Innovation Management, Entrepreneurship and Sustainability (IMES 2019) (pp. 161-172). Prague University of Economics and Business.

Dvoulety, O. (2020). What prevents Czech women from choosing entrepreneurship as a career pathway? In O. Dvoulety, M. Lukes \& J. Misar (Eds.), Proceedings of the 8th International Conference Innovation Management, Entrepreneurship and Sustainability (IMES 2020) (pp. 133-139). Prague University of Economics and Business.

Elliot, A. J., \& Church, M. A. (1997). A hierarchical model of approach and avoidance achievement motivation. Journal of Personality and Social Psychology, 72(1), 218-232. https://doi.org/10.1037/0022-3514.72.1.218

Engel, Y., Noordijk, S., Spoelder, A., \& van Gelderen, M. (2021). Self-compassion when coping with venture obstacles: Loving-kindness meditation and entrepreneurial fear of failure. Entrepreneurship Theory and Practice, 45(2), 263-290. https://doi.org/10.1177/1042258719890991

European Commission. (2019). 2019 SBA Fact Sheet \& Scoreboard. European Commission. https://ec.europa.eu/docsroom/documents/38662/attachments/1/translations/en/renditions/nativ e

Eurostat. (2020). Business demography by size class (from 2004 onwards, NACE Rev. 2) [Data set]. Eurostat. https://ec.europa.eu/eurostat/en/web/products-datasets/-/BD_9BD_SZ_CL_R2

Gómez-Araujo, E., Lafuente, E., Vaillant, Y., \& Gómez Núñez, L. M. (2015). The differential impact of self-confidence, reference models and the fear of failure in young entrepreneurs. Innovar, 25(57), 157-174. https://doi.org/10.15446/innovar.v25n57.50358

Grabowska, M., Krzywda, J., Łęgowik-Świącik, S., \& Stantejsky, S. (2018). Selected aspects of entrepreneurship in Poland and Austria. Scientific Papers of Silesian University of Technology, 116(1995), 37-50. https://doi.org/10.29119/1641-3466.2018.116.3

Heinzel, J., Askari, H., \& Geiberl, R. (2014). How do certain factors affect the fear of failure in entrepreneurship? In 4th Annual International Conference on Business Strategy and Organizational Behavior (BizStrategy 2014) (pp. 21-26). Global Science and Technology Forum.

Hessels, J., Grilo, I., Thurik, R., \& van der Zwan, P. (2011). Entrepreneurial exit and entrepreneurial engagement. Journal of Evolutionary Economics, 21(3), 447-471. https://doi.org/10.1007/s00191-010-0190-4

Holienka, M., Jancovicova, Z., \& Kovacicova, Z. (2016). Drivers of women entrepreneurship in Visegrad countries: GEM evidence. Procedia - Social and Behavioral Scieces, 220(2016), 124-133. https://doi.org/10.1016/j.sbspro.2016.05.476

Holienka, M. (2018). Podnikanie. Podnikavost', tvorba a rozvoj podnikatel'ských nápadov a priležitostí. Univerzita Komenského. https://www.fm.uniba.sk/fileadmin/fm/Veda/projekty/GUESSS/Holienka_2018_2_pre_CD.pdf

Koellinger, P., Minniti, M., \& Schade, C. (2013). Gender differences in entrepreneurial propensity. Oxford Bulletin of Economics and Statistics, 75(2), 213-234. https://doi.org/10.1111/j.14680084.2011.00689.x

Kollmann, T., Stockmann, C., \& Kensbock, J. M. (2017). Fear of failure as a mediator of the relationship between obstacles and nascent entrepreneurial activity - An experimental approach. Journal of Business Venturing, 32(3), 280-301. https://doi.org/10.1016/j.jbusvent.2017.02.002 
Langowitz, N., \& Minniti, M. (2007). The entrepreneurial propensity of women. Entrepreneurship Theory and Practice, 31(3), 341-364. https://doi.org/10.1111/j.1540-6520.2007.00177.x

Lazarus, R. S. (1991). Emotion and adaptation. Oxford University Press.

Leary, M. R., \& Hoyle, R. H. (Eds.). (2009). Handbook of individual differences in social behavior. Guilford Press.

Lukes, M., Zouhar, J., Jakl, M., \& Ocko, P. (2013). Factors influencing entrepreneurial entry: Early-stage entrepreneurs in the Czech Republic. Politická ekonomie, 61(2), 229-247. https://doi.org/10.18267/j.polek.896

Lukes, M., \& Zouhar, J. (2015). Birth and survival of new ventures in the Czech Republic. In The 9th International Days of Statistics and Economics - Conference Proceedings (pp.1034-1041). Prague University of Economics and Business. https://msed.vse.cz/msed_2015/article/109Lukes-Martin-paper.pdf

Lukes, M. (2017). Entrepreneurship development in the Czech Republic. In A. Sauka \& A. Chepurenko (Eds.), Entrepreneurship in transition economies (pp. 209-224). Springer.

Markman, G. D. (2012). Entrepreneurs' competencies. In J. R. Baum, M. Frese \& R. Baron (Eds), The Psychology of Entrepreneurship (pp. 67-92). Psychology Press.

Martin, A. J., \& Marsh, H. W. (2003). Fear of failure: Friend or foe? Australian Psychologist, 38(1), 3138. https://doi.org/10.1080/00050060310001706997

Martins, I., Monsalve, J. P. P., \& Martinez, A. V. (2018). Self-confidence and fear of failure among university students and their relationship with entrepreneurial orientation: Evidence from Colombia. Academia Revista Latinoamericana de Administración, 31(3), 471-485. https://doi.org/10.1108/ARLA-01-2018-0018

McClelland, D. C., Atkinson, J. W., Clark, R. A., \& Lowell, E. L. (1953). The achievement motive. Appleton-Century-Crofts.

McGregor, H. A., \& Elliot, A. J. (2005). The shame of failure: Examining the link between fear of failure and shame. Personality and Social Psychology Bulletin, 31(2), 218-231. https://doi.org/10.1177/0146167204271420

McMullen, J. S., \& Dimov, D. (2013). Time and the entrepreneurial journey: The problems and promise of studying entrepreneurship as a process. Journal of Management Studies, 50(8), 1481-1512. https://doi.org/10.1111/joms.12049

Minniti, M. (2005). Entrepreneurship and network externalities. Journal of Economic Behavior \& Organization, 57(1), 1-27. https://doi.org/10.1016/j.jebo.2004.10.002

Minniti, M., \& Nardone, C. (2007). Being in someone else's shoes: The role of gender in nascent entrepreneurship. Small Business Economics, 28(2), 223-238. https://doi.org/1007/s11187-0069017-y

Mitchell, J. R., \& Shepherd, D. A. (2011). Afraid of opportunity: The effects of fear of failure on entrepreneurial action. Frontiers of Entrepreneurship Research, 31(6), 1.

Pilkova, A., Rehak, J., \& Kovacicova, Z. (2012). Senior entrepreneurship in Slovakia: Global entrepreneurship monitor (GEM) evidences. In J. Rehak \& Z. Kovacicova (EDS.), Different perspectives of active ageing (pp. 100-117). Comenius University in Bratislava.

Pilkova, A., \& Holienka, M. (2017). Entrepreneurship development in Slovakia. In A. Sauka \& A. Chepurenko (Eds.), Entrepreneurship in transition economies (pp. 225-241). Springer. 
Portes, A. (1998). Social capital: Its origins and application in modern sociology. Annual Review of Sociology, 24, 1-24. https://doi.org/10.1146/annurev.soc.24.1.1

Ramos-Rodríguez, A. R., Medina-Garrido, J. A., Lorenzo-Gómez, J. D., \& Ruiz-Navarro, J. (2010). What you know or who you know? The role of intellectual and social capital in opportunity recognition. International Small Business Journal, 28(6), 566-582. https://doi.org/10.1177/0266242610369753

Randolph-Seng, B., Mitchell, J. R., \& Mitchell, R. K. (2014). Introduction: Historical context, present trends and future directions in entrepreneurial cognition research. In J. R. Mitchell, R. K. Mitchell \& B. Randolph-Seng (Eds.), Handbook of entrepreneurial cognition (pp. 1-60). Edward Elgar Publishing. https://doi.org/10.4337/9781781006597.00010

Rehak, J., Pilkova, A., Jancovicova, Z., \& Holienka, M. (2017). Do senior entrepreneurs differ from youth entrepreneurs? Evidences from global entrepreneurship monitor. In O. Dvoulety, M. Lukes \& J. Misar, (Eds.), Proceedings of the 5th International Conference Innovation Management, Entrepreneurship and Sustainability (IMES 2017) (pp. 836-848). Prague University of Economics and Business.

Ruminski, R. (2015). Recent developments of entrepreneurship in Poland: The country entrepreneurial profile. Journal of Enterprising Culture, 23(02), 237-269. https://doi.org/10.1142/S0218495815500089

Slovak Business Agency. (2018). Male a stredne podnikanie v cislach v roku 2018 [Small and mediumsized entrepreneurship in figures in 2018]. Slovak Business Agency. http://www.sbagency.sk/sites/default/files/msp_v_cislach_2018.pdf

Shepherd, D. A., \& Haynie, J. M. (2011). Venture failure, stigma, and impression management: A selfverification, self-determination view. Strategic Entrepreneurship Journal, 5(2), 178-197. https://doi.org/10.1002/sej.113

Shinnar, R. S., Giacomin, O., \& Janssen, F. (2012). Entrepreneurial perceptions and intentions: The role of gender and culture. Entrepreneurship Theory and Practice, 36(3), 465-493. https://doi.org/10.1111/j.1540-6520.2012.00509.x

Szerb, L., Komlósi, É., \& Páger, B. (2017). A multidimensional, comparative analysis of the regional entrepreneurship performance in the Central and Eastern European EU member countries. In A. Sauka \& A. Chepurenko (Eds.), Entrepreneurship in transition economies (pp. 35-56). Springer. https://doi.org/10.1007/978-3-319-57342-7_3

Terek, E., Nikolić, M., Ćoćkalo, D., Božić, S., \& Nastasić, A. (2017). Enterprise potential, entrepreneurial intentions and envy. Central European Business Review, 6(2), 30-41. https://doi.org/doi: 10.18267/j.cebr.178

Trang, T. V., Do, Q. H., \& Luong, M. H. (2019). Entrepreneurial human capital, role models, and fear of failure and start-up perception of feasibility among adults in Vietnam. International Journal of Engineering Business Management, 11, 1-11. https://doi.org/10.1177/1847979019873269

Unger, J. M., Rauch, A., Frese, M., \& Rosenbusch, N. (2011). Human capital and entrepreneurial success: A meta-analytical review. Journal of Business Venturing, 26(3), 341-358. https://doi.org/10.1016/j.jbusvent.2009.09.004

Vancea, M., \& Utzet, M. (2017). Does unemployment and precarious employment lead to increasing entrepreneurial intentions among young people? Results from a survey-based study in Spain. Central European Business Review, 6(2), 5-17. https://doi.org/10.18267/j.cebr.176

Verheul, I., \& Van Mil, L. (2011). What determines the growth ambition of Dutch early-stage entrepreneurs? International Journal of Entrepreneurial Venturing, 3(2), 183-207. https://doi.org/10.1504/IJEV.2011.03934 
Wagner, J., \& Sternberg, R. (2004). Start-up activities, individual characteristics, and the regional milieu: Lessons for entrepreneurship support policies from German micro data. The Annals of Regional Science, 38(2), 219-240. https://doi.org/10.1007/s00168-004-0193-x

Wagner, J. (2007). What a difference a Y makes - Female and male nascent entrepreneurs in Germany. Small Business Economics, 28(1), 1-21. https://doi.org/10.1007/s11187-005-0259-x

Wennberg, K., Pathak, S., \& Autio, E. (2013). How culture moulds the effects of self-efficacy and fear of failure on entrepreneurship. Entrepreneurship \& Regional Development, 25(9-10), 756-780. https://doi.org/10.1080/08985626.2013.862975

Welpe, I. M., Sporrle, M., Grichnik, D., Michl, T., \& Audretsch, D. B. (2012). Emotions and opportunities: The interplay of opportunity evaluation, fear, joy, and anger as antecedent of entrepreneurial exploitation. Entrepreneurship Theory and Practice, 36(1), 69-96. https://doi.org/10.1111/j.15406520.2011.00481.x

Wood, M. S., McKelvie, A., \& Haynie, J. M. (2014). Making it personal: Opportunity individuation and the shaping of opportunity beliefs. Journal of Business Venturing, 29(2), 252-272. https://doi.org/10.1016/j.jbusvent.2013.02.001

Wyrwich, M., Sternber, R., \& Stuetzer, M. (2019). Failing role models and the formation of fear of entrepreneurial failure: A study of regional peer effects in German regions. Journal of Economic Geography, 19(3), 567-588. https://doi.org/10.1093/jeg/lby023

The research article passed the review process. | Received: December 18, 2020; Revised: May 21, 2021; Accepted: June 17, 2021; Pre-published online: October 31, 2021; Published in the regular issue: May 19, 2022. 